\title{
Global Climatic Classification Based on Seasonal Distribution of Non-Precipitation Areas
}

\author{
Takashi Eguchi*1), Jun Matsumoto*1), Harumi Kitajima*2), Kazutaka Iwasaki*3), \\ Masato ShINodA ${ }^{* 1)}$, Takehiko MiKami*4), Kooiti MaSUdA ${ }^{* 5)}$
}

\begin{abstract}
Precipitation is an important climatic element to clarify the world climate, but the precise global distribution of precipitation in less than a month has not been analyzed. The authors take notice of the non-precipitation area (NPA) and intend to clarify the intra-seasonal fluctuation and seasonal difference of global precipitation distribution using 10-day data generated from daily drecipitation data during the First GARP Global Experiment (FGGE). We also intend to present a map of climatic classification based on the seasonal distribution of the non-precipitation areas, and to discuss the climatic boundaries between the east and west of each continent.

On the basis of the seasonal composite map of non-precipitation areas (NPAs), we define three NPAs, i.e. Min-NPA, Mean-NPA, and Max-NPA. In the Northern Hemisphere, during DJF season (from December to February), the Mean-NPA widely extends between the northern part of Africa and the Tibetan Plateau. While during JJA season (from June 11 to August 20), it is distributed in the northern part of Africa and in West Asia. In the Southern Hemisphere, during DJF season the Mean-NPAs are limited along the west coasts of each continent. Whereas, during JJA season they extend widely in each continent, and the Min-NPA appears in the northeastern part of South America. The intra-seasonal fluctuation of NPAs is large in the northern part of North America and Australia during DJF season.

Based on the distribution of NPAs during two seasons, we define four kinds of seasonal NPAs, i.e. winter and summer Min-NPA (mNPA), winter and summer Mean-NPA (wsNPA), winter Mean-NPA (wNPA), and summer Mean-NPA (sNPA). In the western part of each continent, the mNPA and wsNPA are widely extended and all NPA types are zonally distributed. In the western part of each continent, each seasonal NPA well corresponds to the climatic types of Alisov and KöPPEN. In the eastern part of each continent, however, only wNPAs, if any, appear, which are not well consistent with ALIsov's or KöpPEN's climatic types. The climatic boundaries between the western and eastern parts of each continent are located at the western foot of the highest mountain ranges in each continent, on the basis of the distribution of non-precipitation areas.
\end{abstract}

\section{Introduction}

Precipitation is an important climatic element to clarify the world climate, the climatic change and the climatic division. The distribution of world precipitation has been analyzed based on the monthly or yearly data (e.g. JAEgER, 1976). SuzuKI $(1974,1975)$ has pointed out that on the world monthly precipitation maps, the borders of rain-belts in the low latitude well coincide with the locations of ITCZ which are analyzed on the IGY(1958) World Weather Maps. He also stated that the monthly precipitation maps, not averaged for years, are useful in expressing the structure and change of location of the important atmospheric systems, such as polar frontal zone and ITCZ. But by using monthly data, the intra-seasonal fluctuations of precipitation areas

*1) Department of Geography, University of Tokyo, Hongo, Bunkyo-ku, Tokyo 113, Japan.

*2) Faculty of Economics, Shinshu University, Matsumoto 390, Japan.

*3) Faculty of Letters, Hokkaido University, Sapporo 060, Japan.

*4) Department of Geography, Ochanomizu University, Otsuka, Bunkyo-ku, Tokyo 112, Japan.

*5) Geophysical Institute, University of Tokyo, Yayoi, Bunkyo-ku, Tokyo 113, Japan. 
can not be sufficiently analyzed. Moreover, seasonal changes of climate, such as the onset of monsoon, do not always occur at the end of the month. When the seasonal change does not occur at the end of month, the monthly data include climatic characteristics of two seasons and the seasonal characteristics become obscure. Therefore, it is necessary to analyze the global precipitation on a shorter time scale than a month.

In this paper, we show the global 10-day precipitation maps for the first time. On the basis of these maps, we intend to clarify the intra-seasonal fluctuation and the seasonal difference of precipitation distribution from dynamic climatological point of view. Since bordering lines have a definite meaning, we take notice of the $0.1 \mathrm{~mm}$ isohyet which is the bordering line between the precipitation area and non-precipitation area. The analyses were mainly conducted on the non-precipitation area. Furthermore, we present a map of climatic classification from dynamic climatological point of view and compare the classification of climate by Alisov (1950) and KöPPEN (1918). In comparison with the Alisov's climatic classification, we intend to determine the climatic boundary between west and east coasts of the continents, which is one of the main defects of his climatic classification, as has been pointed out by Suzuki(1961).

\section{Data and analysis procedures}

From the dynamic climatological point of view, it is desirable for determining the climatic boundaries to utilize daily data, as SuzUKI (1962) has applied in classifying Japanese climates. However, on a global scale, day to day fluctuations of precipitated areas are so large that it becomes difficult to realize large scale seasonal characteristics of precipitation distribution by using daily data. In addition, there is a problem that the measurement time of precipitation is different among nations. Five-day data or ten-day data are devoid of the defects of both daily and monthly data. In this paper, as the first step, we used 10-day data. The first GARP (Global Atmospheric Research Program) Global Ex- oeriment (FGGE) was carried out from December 1978 to November 1979, organized by the World Meteorological Organization (WMO) and the International Council of Scientific Unions (ICSU). We could obtain daily precipitation data from almost all over the world during the experimental period.

We used FGGE Level II-c Precipitation and Snow Data Set, which was compiled at the National Climatic Data Center, Asheville, U.S.A. About 6,000 observational stations were selected among approximately 30,000 stations to achieve as uniform distribution as possible. Since the delimiting time between days is different among countries, we redefined the date for each daily observation, so that the longest part of 0-24 GMT of the day overlaps the observation "day", by comparing with the 6 (or 12 or 24) hours precipitation data from FGGE level II-b Data Set. Based on these daily precipitation data, we made 36 maps of 10-day precipitation, which have been already published by Matsumoto et al. (1985).

In this study, the numerals $I, \mathbb{I}$, and $\mathbb{I I}$ in each month indicate the period from day 1st to 10th, from 11th to 20 th and from 21 st to the end of month, respectively. The 10day precipitation data used in this paper are nine 10-day data from December-I to February-III (DJF season) and seven 10-day data from June-II to August-II (JJA season). The global simultaneity of abrupt seasonal change is discussed in the paper by SHINoda et al. (1986). Since the abrupt seasonal changes in precipitation distribution were recognized around June-I and around August-III, the JJA season was defined as mentioned above. We drew isohyets by hand and defined the area where the precipitation is below $0.1 \mathrm{~mm}$ as "non-precipitation area (NPA)" on each 10-day precipitation map.

The boundary lines of NPAs $(0.1 \mathrm{~mm}$ isohyets) on each map were piled up to the composite map for each DJF and JJA season. And in order to discuss the intra-seasonal fluctuation, we classified NPAs in each season into three ranks, "Minimum NPA (Min-NPA)", "Mean NPA (Mean-NPA)" and "Maximum NPA (Max-NPA)". The Min-NPA is an area where the total precipitation for each season is below $0.1 \mathrm{~mm}$. The Mean-NPA is inside the 
area where $0.1 \mathrm{~mm}$ isohyets are concentrated on each composite map. But in the case that $0.1 \mathrm{~mm}$ isohyets are not concentrated, the Mean-NPA is the area where the precipitation below $0.1 \mathrm{~mm}$ is recorded in more than half of the season. When the $0.1 \mathrm{~mm}$ isohyets are concentrated, the climate differs abruptly across the boundary line of Mean-NPA. Thus in this case we express that the boundary line of Mean-NPA is "sharp". And when they are not concentrated, we express that the boundary line of Mean-NPA is "not sharp" or "obscure". The Max-NPA is an area where 0.1 $\mathrm{mm}$ isohyet reaches at least one 10-day period.

\section{Distribution and intra-seasonal fluctuation of non-precipitation areas}

\section{DJF (Northern winter) season}

In the Northern Hemisphere, the Min-NPAs are distributed between the equator and $30^{\circ} \mathrm{N}$ except the Tibetan Plateau (Figure 1). In Africa and Middle East, two Min-NPAs are distributed, west of $40^{\circ} \mathrm{E}$ meridian and east of $45^{\circ} \mathrm{E}$. The western Min-NPA extends zonally and is almost distributed in the Sahara. This Min-NPA is broader than any other MinNPAs during this season. The eastern MinNPA in Somalia and the southeastern part of Arabia is the only region where the Min-NPA appears along the east coasts of continents. This Min-NPA is not distributed zonally like the western one. It is distributed from around the equator to about $25^{\circ} \mathrm{N}$ and is located about 5 degrees southward compared with the western one. The northern and southern boundaries of Mean-NPA extends zonally westward to $70^{\circ} \mathrm{E}$ and they are sharp. The southern and western boundaries of it, east of $70^{\circ} \mathrm{E}$, are also sharp. However, the northern boundary of it is not so sharp.

In South and Southeast Asia between the equator and about $30^{\circ} \mathrm{N}$ (east of $80^{\circ} \mathrm{E}$ ), the Min- and Mean-NPAs appear along the west coast and to the west of mountain ranges (Figure 1). The eastern boundaries of the MeanNPAs are limited by the mountain ridge, and the fluctuation of $0.1 \mathrm{~mm}$ isohyets on the composite map is smaller along the eastern boundaries of the Mean-NPA than the western boundaries of them (Figure 2). The southern boundaries of the Mean-NPAs in South and Southeast Asia are around $10^{\circ} \mathrm{N}$. However, the northern boundaries of them are located around $30^{\circ} \mathrm{N}$ in India and Burma, whereas they are located around $20^{\circ} \mathrm{N}$ in Thailand and the Philippines (Figure 1).

From December-II to January-I, the NPAs on each 10-day precipitation map approximately coincide with the Max-NPA, which is dis-

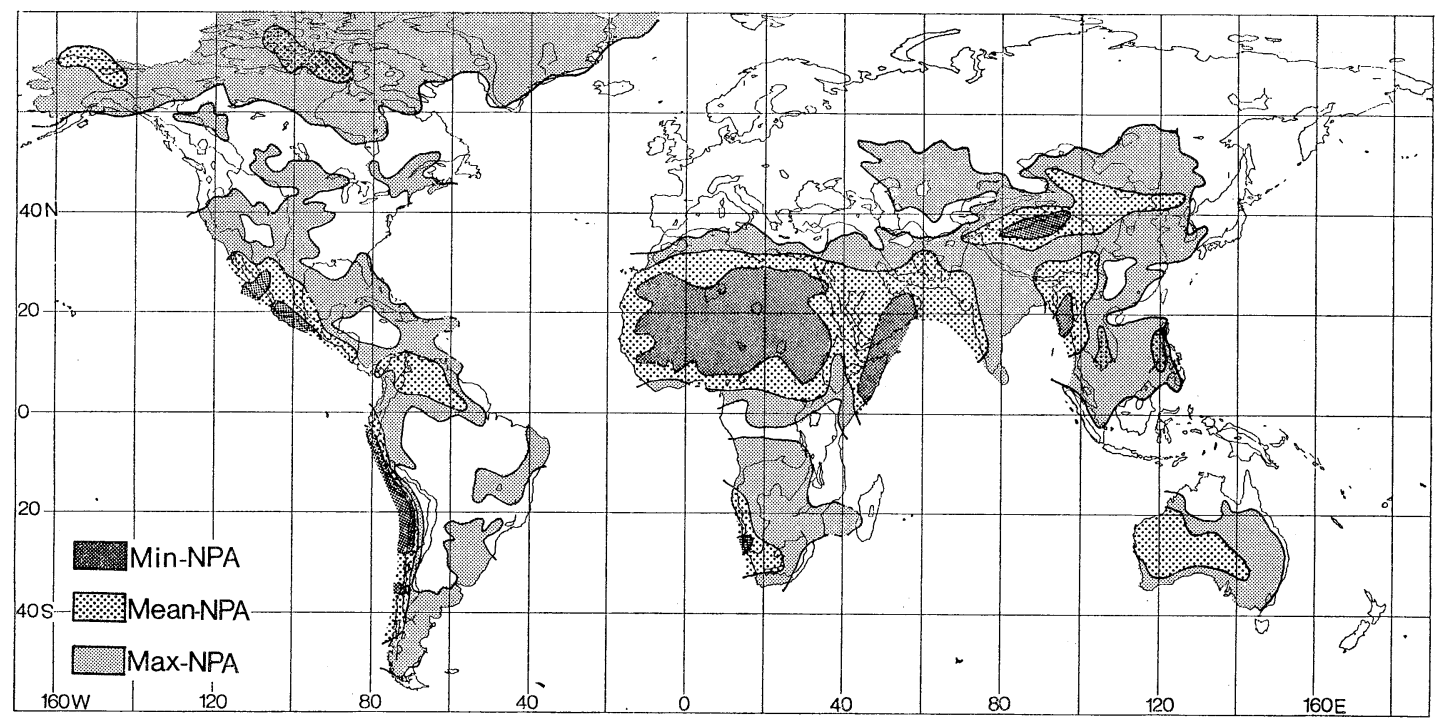

Figure 1. Distribution of non-precipitation areas (NPAs) from December to February (DJF season). 


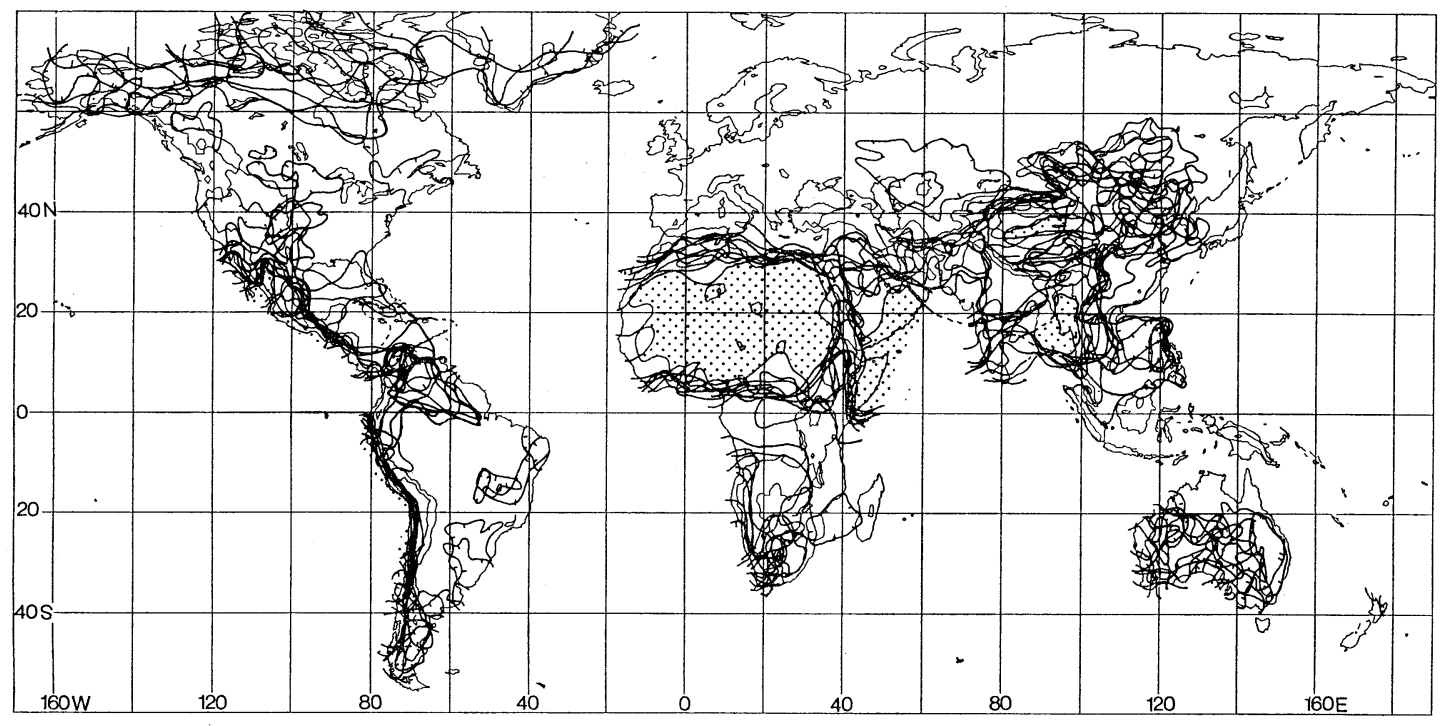

Figure 2. Composite map of $0.1 \mathrm{~mm}$ isohyets from December to February (DJF season). Shaded area : Minimum non-precipitation area (Min-NPA)

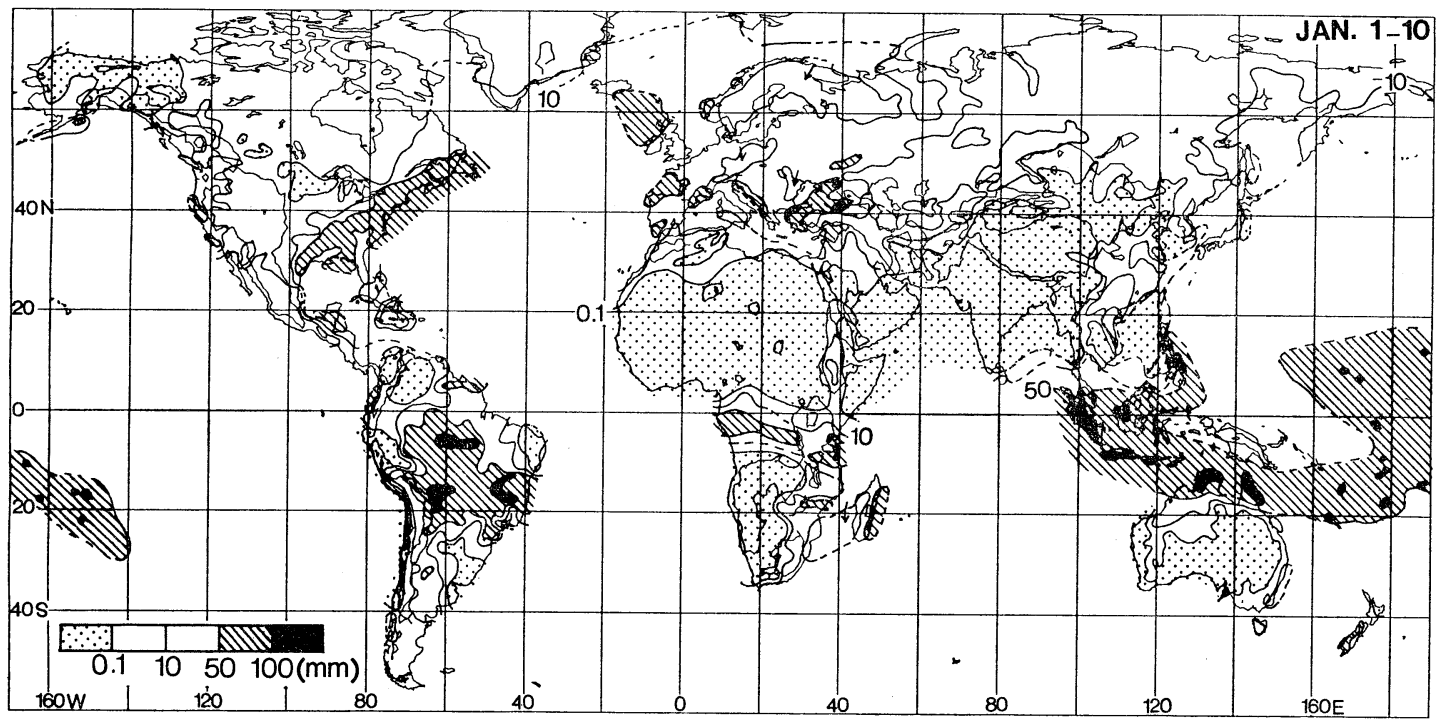

Figure 3. Ten-day precipitation distribution from 1st to 10th in January (January-I).

tributed from the northern part of Africa to East and Southeast Asia, and cover the MeanNPAs of Africa, Middle East, India, Burma, Thailand, the Philippines, and moreover the Tibetan Plateau. As an example, the precipitation distribution during January-I is shown in Figure 3. After January- $\mathbb{I}$, the NPAs in Africa and Middle East is separated from those of the Tibetan Plateau by the precipitation area along the southern foothill of the Himalayas. Those around Burma are separated from those of the Tibetan Plateau by the zonal area between $30^{\circ} \mathrm{N}-35^{\circ} \mathrm{N}$ where the amount of 10-day precipitation is $0.1-10 \mathrm{~mm}$.

The Mean-NPA is extended only west of $85^{\circ} \mathrm{W}$ in Central America, with two separated 
Min-NPAs along the west coast (Figure 1). The eastern boundary of Mean-NPA is sharp, but the northern and southern boundaries are not so sharp as the eastern one (Figure 2). The NPA in Central America extends to the northern part of South America on every map after January- $\mathbb{I}$. The NPA in the northern part of South America between the equator and $10^{\circ} \mathrm{N}$ appears to the east of the Andes and fluctuates from northwest to southeast centered at Venezuela.

The Tibetan Plateau is the only region where the Min- and Mean-NPAs appear between $30^{\circ} \mathrm{N}$ and $50^{\circ} \mathrm{N}$. The southern boundary of the Mean-NPA in the Tibetan Plateau has already mentioned in connection with the NPAs in India and Burma. The western and northwestern boundaries of it are sharp, while the eastern and northeastern boundaries of it are obscure (Figure 2).

The northern part of North America is the only region where the Mean-NPA appears north of $70^{\circ} \mathrm{N}$. There are two centers of the NPA, which are located around Alaska and to the northwest of the Hudson Bay (Figure 1). In these regions, the NPAs are distributed on every map in February. But during the other periods the NPAs do not appear continuously. The amount of precipitation is generally below $10 \mathrm{~mm}$, and the boundary lines of the Mean-NPAs are not so sharp as those in the lower latitudes.

In the Southern Hemisphere, the Min-NPAs are located along the west coast of southern Africa (the Namib Desert) and the west coast of South America (the Atacama Desert) (Figure 1). They do not appear along the west coast of Australia. The Mean-NPA is distributed between $15^{\circ} \mathrm{S}$ and $25^{\circ} \mathrm{S}$ in southern Africa and Australia, and between the equator and $45^{\circ} \mathrm{S}$ in South America. The Max-NPAs are distributed broadly in comparison with the Minand Mean-NPAs.

In southern Africa, the eastern boundary of the Mean-NPA is sharp between $15^{\circ} \mathrm{S}$ and $25^{\circ} \mathrm{S}$, but that between $25^{\circ} \mathrm{S}$ and $35^{\circ} \mathrm{S}$ largely fluctuates (Figure 2).

In Australia, the distribution of NPAs on each map is different and the fluctuation of $0.1 \mathrm{~mm}$ isohyets is large. Since the $0.1 \mathrm{~mm}$ isohyets on the composite map are not concentrated, the boundary line of Mean-NPA is more obscure than that in other regions (Figure 2). The frequency of appearance of the NPAs is higher in the western part than in the eastern part.

In South America, the Min- and Mean-NPAs are distributed along the west coast (Figure 1). The northern and eastern boundaries of these NPAs are sharp. In particular, along the

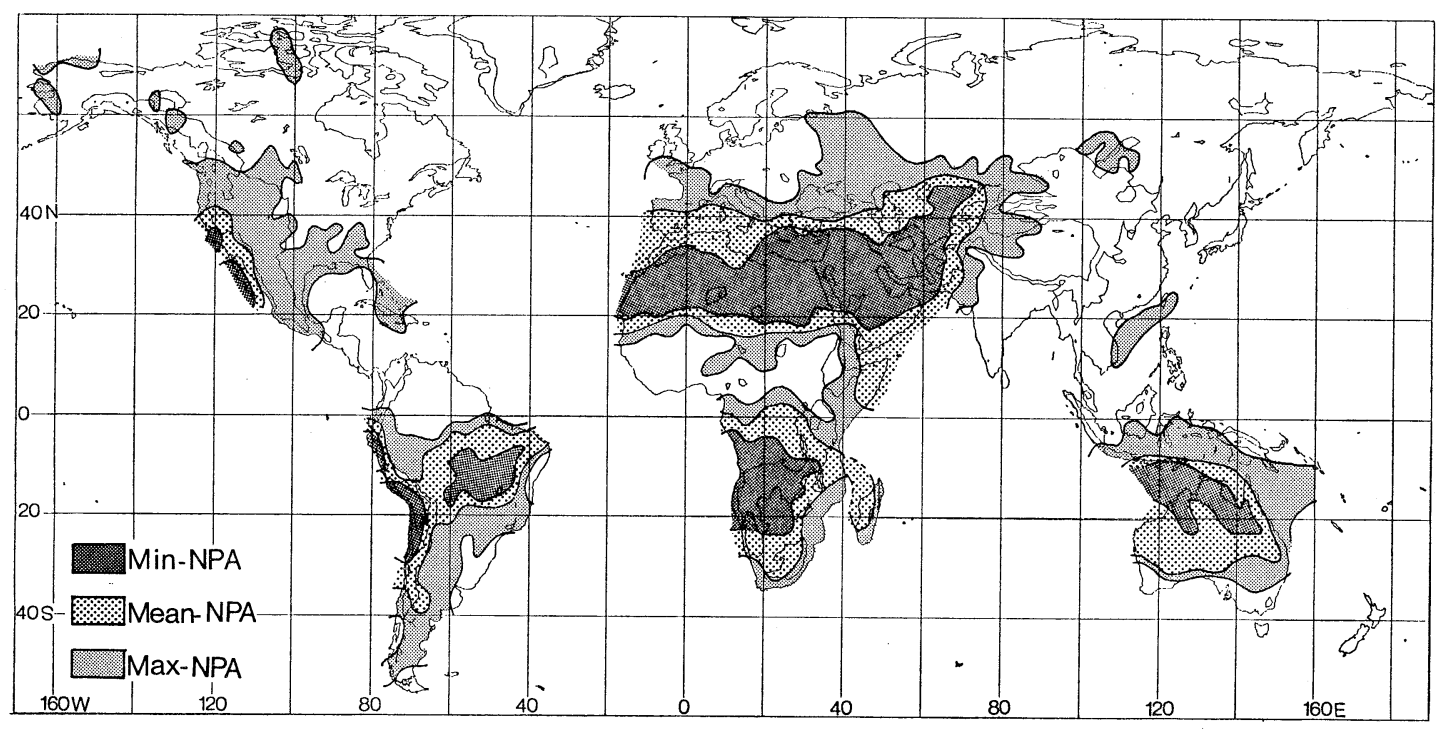

Figure 4. Distribution of non-precipitation areas (NPAs) from June 11 to August 20 (JJA season). 


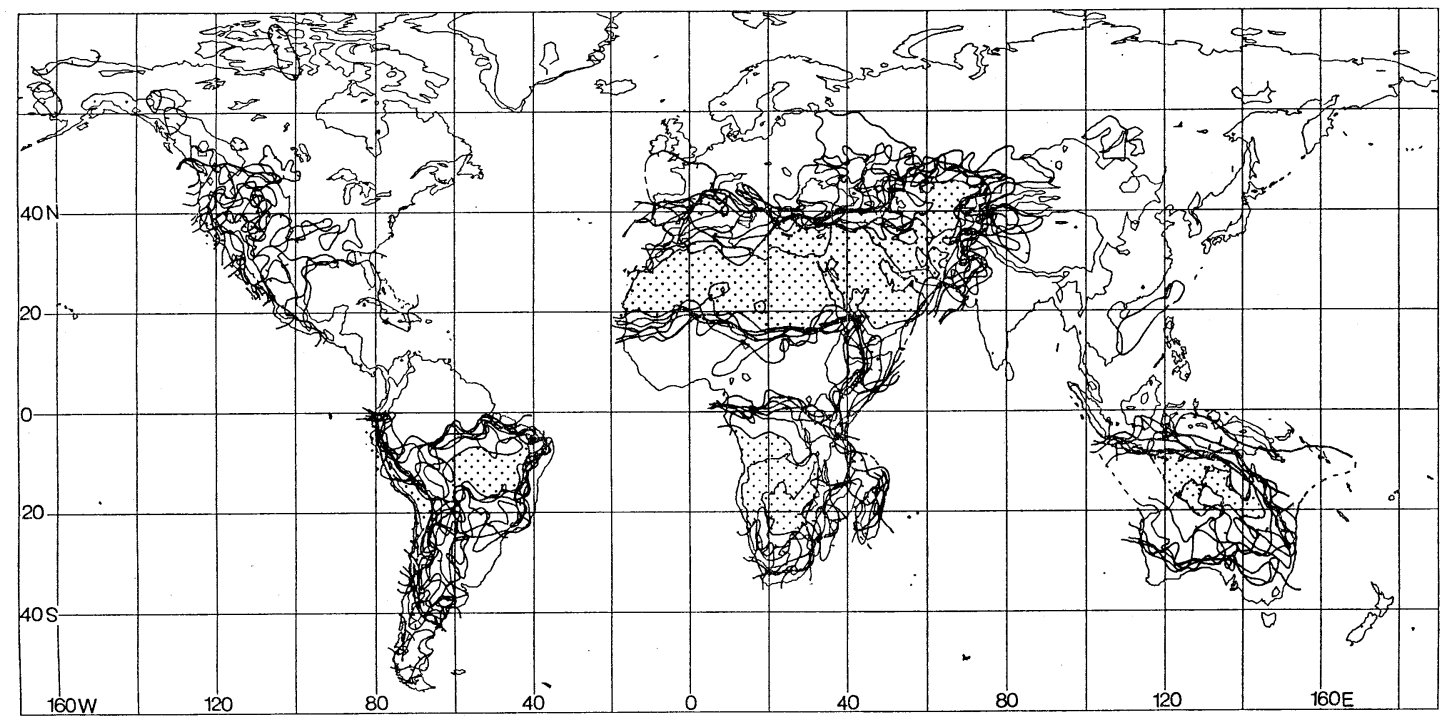

Figure 5. Composite map of $0.1 \mathrm{~mm}$ isohyets from June 11 to August 20 (JJA season). Shaded area : Minimum non-precipitation area (Min-NPA).

eastern boundary, the transition from the MinNPA to the Max-NPA is abrupt (Figure 2). On the other hand, the NPAs between $40^{\circ} \mathrm{S}$ and $50^{\circ} \mathrm{S}$ fluctuates largely in comparison with the northern NPAs.

\section{JJA (Northern summer) season}

In the Northern Hemisphere, during JJA season, the NPAs appear mainly between $20^{\circ} \mathrm{N}$ and $40^{\circ} \mathrm{N}$ in Africa, the western part of Eurasian Continent and North America. But there are no NPAs in the eastern part of the Eurasian Continent (Figure 4).

The NPAs extend in northern Africa, Arabia, and West Asia (Figure 4). The NPAs are distributed almost zonally in Africa and Arabia, but in West Asia they extend northeastward. The Min-NPA extends in Africa, the eastern part of the Mediterranean, Arabia, and West Asia and this is the broadest Min-NPA during this season. The fluctuation of NPAs is relatively small in these areas, in particular, the southern boundary is sharp (Figure 5). The eastern boundary is also sharp. The $0.1 \mathrm{~mm}$ isohyets are concentrated meridionally between $70^{\circ} \mathrm{E}$ and $75^{\circ} \mathrm{E}$. However, the northern boundary is not sharp. To the west of $20^{\circ} \mathrm{E}$, $0.1 \mathrm{~mm}$ isohyets run along the north coast of Africa from June-II to July-II. But from
July-III, the NPA covers over the Mediterranean and the boundary of it runs along the south coast of Europe and cross the Iberian Peninsula along $40^{\circ} \mathrm{N}$. The precipitation distribution map for June-III is shown in Figure 6 , as an example of JJA situation.

In North America, the Min- and Mean-NPAs are distributed along the west coast (Figure 4). The $0.1 \mathrm{~mm}$ isohyets are not so concentrated and the fluctuation of NPAs are large (Figure $5)$.

In the Southern Hemisphere, the Min-NPAs are distributed mainly between $5^{\circ} \mathrm{S}$ and $30^{\circ} \mathrm{S}$ (Figure 4). The northern and southern boundaries of the Mean-NPAs are different on each continent. In Africa, the Mean-NPA extends almost all the part of Africa south of the equator. The $0.1 \mathrm{~mm}$ isohyets are concentrated along the equator (Figure 5). The northern boundary of the Mean-NPA is close to that of the Max-NPA. The southeastern and southern boundaries of the Mean-NPA are not so sharp as the northern one. In the western part of Madagascar, the Mean-NPA appears and its eastern boundary is sharp.

In Australia, the Min-NPA is distributed between $10^{\circ} \mathrm{S}$ and $20^{\circ} \mathrm{S}$ (Figure 4). The northern and eastern boundaries of the MeanNPA are sharp and are close to those of the 


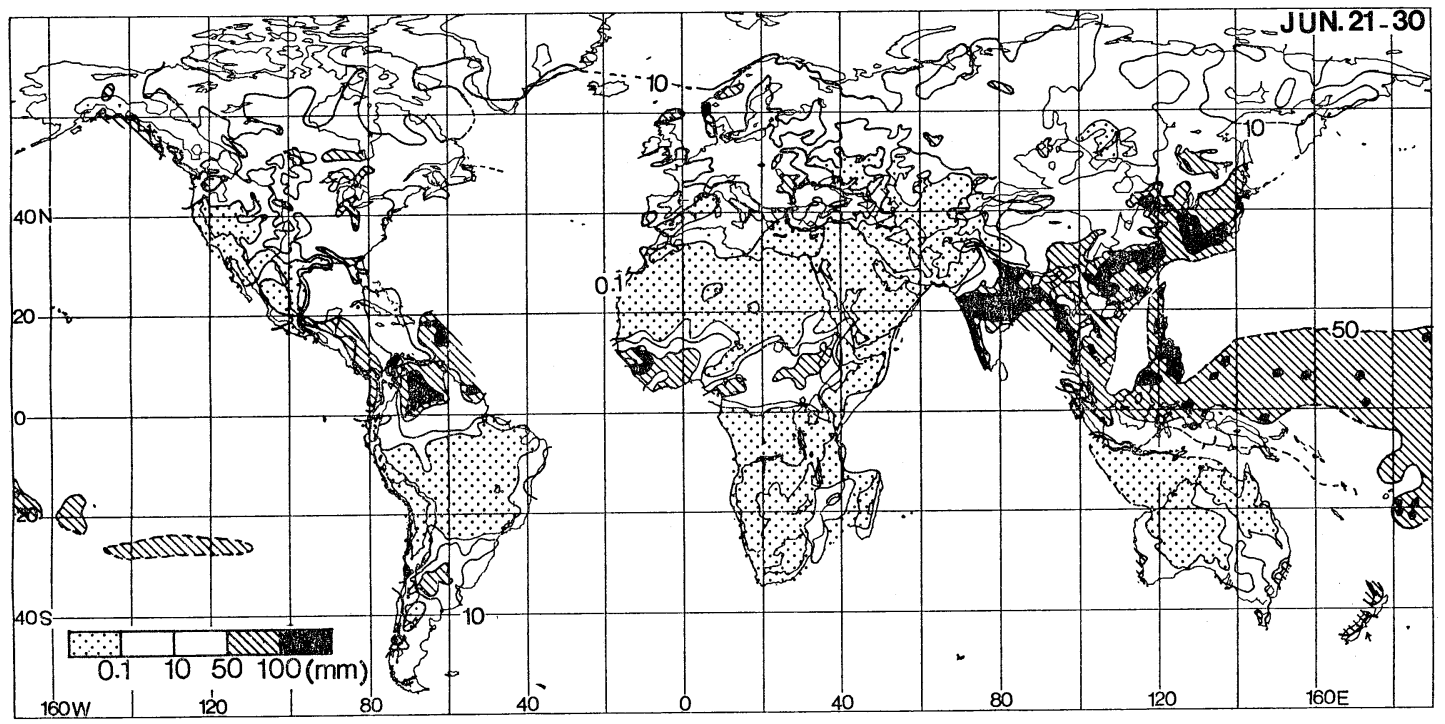

Figure 6. Ten-day precipitation distribution from 21st to 30 th in June (June-III).

Min-NPA. On the other hand, the southern boundary of the Mean-NPA is not so sharp as the northern one. In particular, in the southeastern part of Australia, the $0.1 \mathrm{~mm}$ isohyets largely fluctuate (Figure 5). The southern boundary of the Mean-NPA is close to the southern boundary of the Max-NPA.

In South America, two Min-NPAs are distributed along the west coast, and another one is located between $5^{\circ} \mathrm{S}$ and $20^{\circ} \mathrm{S}$ in the northeastern part of the Brazilian Plateau (Figure 4). The latter is separated from that of the west coast by the precipitation area to the east of the Andes. But the Mean- and Max-NPAs extend in these two areas. The northern and eastern boundaries of Mean-NPA are sharp, however, the southern boundary of it is not sharp.

\section{Climatic classification based on seasonal distribution of non-precipitation areas}

In this chapter, we discuss the difference of the NPAs between DJF and JJA season and present a tentative map of climatic classification based on the seasonal change of the distribution of NPAs.

We pile up the boundaries of Min- and Mean-NPAs of both seasons of each hemisphere and based on the seasonal change of the Minand Mean-NPAs, four areas are divided. These are, winter and summer Min-NPA (mNPA), winter and summer Mean-NPA (wsNPA), summer Mean-NPA (sNPA), and winter Mean-NPA (wNPA). We call these NPAs as seasonal NPAs. The mNPA coincides with the area which is included in the MinNPA during both seasons. The wsNPA is the area which is included in the Mean-NPA during both seasons, for convenience, excluding mNPA. The SNPA is the area which is included in the Mean-NPA only in summer, and wNPA is that in winter. Including other areas (precipitation areas), we can divide five climatic regions over the world based on the non-precipitation areas. A map of climatic classification is shown in Figure 7. This map is tentative, because it is based on only one year data, and because the data are insufficient over the ocean.

These seasonal NPAs are distributed between the equator and $50^{\circ}$ in latitude, with the exception of the northern part of North America. They extend wider in winter than in summer in each Hemisphere. In particular, Africa and Australia are almost covered with seasonal NPAs. The mNPAs are distributed in the Sahara, the southeastern part of Arabia and the southern part of the California Peninsula in the Northern Hemisphere, between $18^{\circ} \mathrm{N}$ 


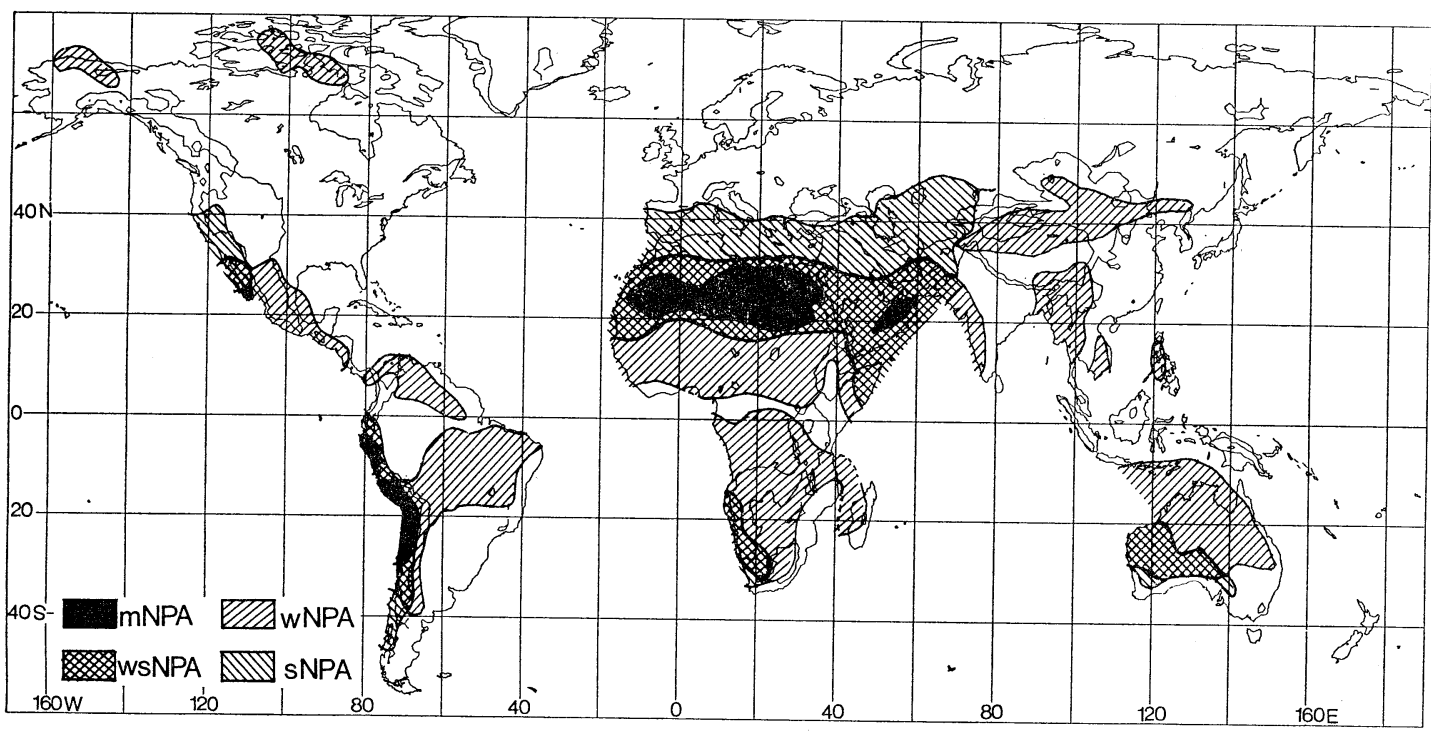

Figure 7. A tentative map of climatic classification based on the seasonal distribution of non-precipitation areas.

and $30^{\circ} \mathrm{N}$. But they are located only along the west coast of South America in the Southern Hemisphere. The mNPA in the Sahara is the largest area and distributed zonally. The mNPA in Arabia is much smaller than that of the Sahara and is not distributed zonally. This $\mathrm{mNPA}$ is separated from the mNPA in the Sahara by the precipitation area during DJF season. The mNPAs in South America are distributed between the equator and $30^{\circ} \mathrm{S}$ along the west coast. They are separated by the narrow area around $12^{\circ} \mathrm{S}$, being precipitated in one 10-day period during JJA season.

The wsNPAs are mainly located around the mNPAs, as well as along the west coast of South Africa and the western and central parts of Australia. In the Northern Hemisphere, the wsNPAs are distributed generally between $15^{\circ} \mathrm{N}$ and $23^{\circ} \mathrm{N}$. In southern Arabia and Somalia, this area extends southward as far as $3^{\circ} \mathrm{N}$. The northern and southern boundaries in the northern part of Africa and Middle East run zonally. In the Southern Hemisphere, the wsNPAs are distributed mainly along the west coasts, as well as in the central part of Australia. The latitudinal distribution of wsNPA is different on each continent. The locations of the wsNPAs are almost determined by the MeanNPAs during DJF season. In South Africa and Australia, where the mNPAs do not appear, the boundaries of wsNPAs are rather obscure in comparison with those in other continents.

The wNPAs are distributed widely in both hemispheres and the wNPAs are much larger than the sNPAs. The wNPAs are located equatorward of the wsNPAs. However, in the western part of the Eurasian Continent and northern part of South America, the wNPAs appear separated from the wsNPAs. In the Southern Hemisphere, the wNPAs are distributed not only north of the wsNPAs but east of them. In particular, the large wNPA is located around the Brazilian Plateau in South America. The sNPA from the Mediterranean to West Asia is distributed largely and zonally. However, they are not located in the eastern part of the Eurasian Continent and the central and eastern part of North America. In the Southern Hemisphere, the sNPAs are distributed south of $30^{\circ} \mathrm{S}$, and almost along the west coast of the continent. These sNPAs are smaller than those in the Northern Hemisphere.

The distribution pattern of the seasonal NPAs is different in each region. The zonal belt of wNPA, wsNPA and SNPA is arranged from south to north between $20^{\circ} \mathrm{W}$ and $70^{\circ} \mathrm{E}$, over North Africa and the western part of the Eurasian Continent. The latitudinal width of each area is about 10-15 degrees and this 
arrangement indicates that the Mean-NPA shifts about 10-15 degrees in latitude poleward in summer and equatorward in winter. But around Somalia, the wsNPA extends equatorward and the wNPA is small. In this area, the seasonal difference of the distribution of Mean-NPA is relatively small. The same zonal arrangement of seasonal NPAs also appears along the west coast of other continents. The latitudinal width of the sNPAs are relatively small and that of the wNPAs is large. Moreover, in South America, the wNPA does not appear north of the wsNPA. The wNPA extends not only northward but eastward in the Southern Hemisphere. Along the east coast, these zonal arrangement of the seasonal NPAs do not appear. In Africa and South America, the wNPAs reach the east coast. But their extent is in the small part of east coast and most of the east coasts are not covered with the seasonal NPAs.

We briefly compare our tentative climatic classification with the classification of climate by Alisov (1950) and Köppen (1918). The principle of Alisov's climatic classification, which is based on the prevailing air masses, is shown in Figure 8-A, and that of ours, based on the non-precipitation areas, is also shown in
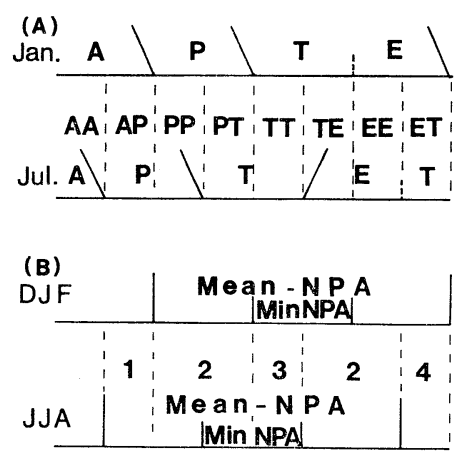

Figure 8. The principle of climatic classification.
(A) Alisov (1950)
A. Arctic air
T. Tropical air E. Equatorial air AA. Arctic
zone AP. Sub-arctic zone PP. Mid-latitude
A. Polar air zone PT. Subtropical zone TT. Tropical zone TE. Equatorial monsoon zone TE. Equatorial monsoon zone EE. Equatorial zone
(B) this paper 1. summer mean non-precipitation area (SNPA) 2. winter and summer mean non- precipitation area (wSNPA) 3. winter and summer minimum non-precipitation area (mNPA) 4. winter mean non-precipitation area (wNPA)

Figure 8-B. If the prevalent tropical air mass brings no precipitation, the wsNPA coincides with Alisov's tropical air mass zone (TT zone). This coincidence is actually recognized in the northern Africa and in Middle East. And in other regions, wsNPAs are almost included in the TT zone, but their extent is much smaller than the TT zone. In South America, the wsNPA south of $30^{\circ} \mathrm{S}$ is distributed in Alisov's subtropical air mass zone (PT zone).

In principle, the wNPA corresponds to Alisov's equatorial monsoon zone (ET zone). In the northern part of South America and Africa, and in the west coastal regions in South and Southeast Asia, this correspondence is recognized. But in the Southern Hemisphere, wNPAs coincide well with the TT zone. The wNPAs in Arctic North America and the Tibetan Plateau, are not caused by the prevalence of tropical air mass, but by that of arctic and polar air masses, respectively.

The sNPA is, in principle, corresponds to the ET zone of Alisov. This correspondence is recognized only in the western part of the continents.

In comparison with KöPpen's climatic classification, the wsNPA is almost included in the desert climate (BW), and the wNPA corresponds to the Savanna climate (Aw), the Steppe climate (BS) and warm with dry winter climate $(\mathrm{Cw})$. And the sNPA includes most of warm with dry summer climate (Cs), and also BS and BW climate.

Considering these relations between our climatic classification and Aursov's and KöPPEN's, the relations are different in each region. In North Africa, the Mediterranean and west of about $70^{\circ} \mathrm{E}$ in the Eurasian Continent, all seasonal NPAs appear and are zonally distributed, and each NPA is well correspondent with each climatic zone of Alisov and Köppen. But east of $70^{\circ} \mathrm{E}$ in the Eurasian Continent, only wNPA appears and it is not zonally distributed. Moreover, the wNPA appears in PT climate whose dry season is summer. The transition of above two regions is sharp and its boundary is located at the western foot of the Himalayas (about $70^{\circ} \mathrm{E}$ ). In the other continents, almost all NPAs appear along the west coasts and in the western part of the continent. Along the east coast 
and in the eastern part of the continent, however, only wNPA appears or NPAs do not appear. The boundary of these two regions is the Rockies in North America, the Andes in South America, the Great Dividing Range in Australia, and the Drakensberg Mountains in South Africa. These results show that the climatic boundary between the eastern and western parts of each continent is located at the western foot of the highest mountain ranges in each continent.

Such climatic difference between east and west of the continents is partly well expressed in KöPPEN's classification, but is not expressed in Alisov's. This paper clearly shows the locations of climatic boundaries between the east and west of the continents. This difference is probably caused by the difference in the structure between eastern and western part of subtropical anticyclones, which has been pointed out by Nakamura (1973), in the case of North Pacific anticyclone. However, further study is needed in order to clarify the causes of our climatic boundaries.

\section{Conclusion}

We showed the intra-seasonal fluctuation and seasonal difference of the distribution of precipitation and to present a tentative map of climatic classification based on the seasonal distribution of the non-precipitation areas.

During DJF season, the NPAs are distributed broader in the Northern Hemisphere than in the Southern Hemisphere. In the Northern Hemisphere, the Min-NPAs are mainly distributed between $10^{\circ} \mathrm{N}$ and $30^{\circ} \mathrm{N}$. The Min-NPA in the Tibetan Plateau is the only region where the Min-NPA appears north of $30^{\circ} \mathrm{N}$. The NPA on each 10-day map extends from the Tibetan Plateau to the northern part of Africa, which is well expressed by the extent of MaxNPA. This is a marked feature during the DJF season. While, in the Southern Hemisphere, the distribution of Min-NPA is limited almost along the west coast of continent, as well as the central part of Australia. In the northern part of North America and Australia, the fluctuation of the boundaries of the MeanNPAs is large.

During JJA season, the Min-NPAs are distributed between $20^{\circ} \mathrm{N}$ and $30^{\circ} \mathrm{N}$ in the Northern Hemisphere and between $10^{\circ} \mathrm{S}$ and $20^{\circ} \mathrm{S}$ in the Southern Hemisphere. In the Northern Hemisphere, the Min-NPA extends in Africa, Arabia and West Asia. In the Southern Hemisphere, the Min-NPA appears widely on each continent and one of the most pronounced features during JJA season is that the Min-NPA is distributed in the northeastern part of South America.

Based on the above results, we discuss the difference of the NPAs between DJF and JJA season, and define four seasonal NPAs, i.e. winter and summer Min-NPA (mNPA), winter and summer Mean-NPA (wsNPA), winter Mean-NPA (wNPA), and summer Mean-NPA (sNPA). These NPAs are mainly distributed between the equator and $50^{\circ}$ in latitude and larger in winter than in summer in both Hemispheres. The mNPAs in the Sahara is large and distributed zonally. In the Southern Hemisphere, the mNPA is distributed only along the west coast of South America. The wsNPAs are mainly distributed between $15^{\circ} \mathrm{N}$ and $23^{\circ} \mathrm{N}$, and around the mNPAs in the Northern Hemisphere. But in the Southern Hemisphere, the wsNPAs are distributed mainly along the west coasts and the latitudinal extent of them are different on each continent.

The wNPAs are distributed much larger than the sNPAs. The wNPAs are mainly distributed equatorward of wsNPAs, but in the eastern part of the continent, only the wNPAs appear. The sNPA between the Mediterranean and West Asia is distributed zonally and large in the Northern Hemisphere. But in the Southern Hemisphere, the sNPAs are small and are mainly distributed south of about $30^{\circ} \mathrm{S}$ and along the west coasts of the continents. The zonal arrangement of seasonal NPAs appears between the equator and $50^{\circ} \mathrm{N}$ from $20^{\circ} \mathrm{W}$ eastward to $70^{\circ} \mathrm{E}$, and also appears along the west coast of continents. But in the eastern part of continents and along the east coast, the zonal arrangement of NPAs does not appear.

A distribution map of each seasonal NPA and precipitation areas is considered to be a map of climatic classification based on the nonprecipitation areas. Though our map is tentative, using only one year data, it partly agrees 
well with that of Alisov and Köppen. Especially, in the western part of the continents, our climatic classification well coincides with them. The climatic boundaries between the eastern and western parts of each continent are located at the western foot of the highest mountain ranges in each continent.

\section{Acknowledgment}

The authors would like to express our sincere thanks to Professor Hideo Suzuki, Department of Geography, University of Tokyo, for his helpful advice.

The authors used Hitac M-280H and S-810 computers in the Computer Center, University of Tokyo to compute and plot the precipitation data. This research was partly supported by University of Tokyo (Project leader: Professor Yutaka SAKagucHI, Department of Geography, University of Tokyo).

(Received October 16, 1985)

(Accepted January 20, 1986)

\section{References}

Alisov, B. P. (1950): Klimaticheskie oblasti zarubezhnykh stran. Moscow, 351p. (German edition, 1954: Die Klimate der Erde. Berlin, 277p.)

JAEgER, L. (1976): Monatskarten des Niederschlages für die ganze Erde. Berichte des Deutschen Wetterdiensts, 139, 2-38.

KöPPEN, W. (1918): Klassifikation der Klimate nach Temperatur, Niederschlag und Jahreslauf. Petermanns Geographische Mitteilungen, 64, 193203, 243-248.

Matsumoto, J., Iwasaki, K., Kitajima, H., Eguchi, T., and Shinoda, M. (1985): Global 10-day precipitation distribution using FGGE daily precipitation data. In SAKAGUCHI, Y. (ed.): Saishuu hyouki-ikou no shizenkankyou no Hendou. (Environmental change during Post Last-Glacial period.) University of Tokyo, Faculty of Science, 81-98.

NAKAMURA, K. (1973): A subtropical anticyclone: a regional system. Geographical Reports of Tokyo Metropolitan University, 8, 111-117.

Shinoda, M., Mikami, T., IWasaki, K., Kitajima, H., Eguchi, T., Matsumoto, J., and MAsuda, K. (1986): Global simultaneity of the abrupt seasonal changes in precipitation during May and June in 1979. Journal of Meteorological Society of Japan, (submitted).

Suzukr, H. (1961): Problems of climatic classification. Chigaku-zassi (Journal of Geography), 72, 215-219.

Suzuki, H. (1962): The classification of the Japanese climates. Chirigaku Hyoron (Geographical Review of Japan), 35, 205-219.

Suzukr, H. (1974): On the utility of monthly data for the dynamic climatology of the world, with special reference of the structure of ITC. Chirigaku Hyoron (Geographical Review of Japan), 47, 684-695.

Suzukr, H. (1975): World precipitation, present and hypsithermal. Bulletin of the Department of Geography University of Tokyo. 7, 1-17.

\title{
無降水域の季節分布による世界の気候区分
}

\author{
江口 卓 ${ }^{12}$ - 松本 淳 ${ }^{12} \cdot$ 北島 晴美 ${ }^{2)}$ ・岩崎 一孝 ${ }^{32}$ \\ 篠田 雅人 ${ }^{1)}$ ・三上 岳彦 ${ }^{4)}$ ・堌田 耕一5)
}

降水量は，世界の気候を明らかにする上で重要な気候 要素であるが，全球の降水量分布の詳細な解析は，月上 り短い時間スケールではこれまで行なわれていない，著 者らは， FGGE 特別観測中の日降水量資料をもと飞作 成した旬降水量資料を用い，特に無降水域酒着目し，全 球の大陸上の降水量分布の季節内変動和よび季節間の相 異を明らかにすることを試みた。 そして，無降水域から
みた世界の気候区分図を提示し，大陸の西岸・東岸の気 候区界について論じた。

無降水域の季節重ね合わせ図にもとづいて 3 種類の無 降水域, 「極小無降水域」「平均無降水域」「極大無降 水域」を定義した. 北半球では, DJF 季 (12〜2月)

飞は，平均無降水域がアフリカ北部からチベット高原に かけて広く分布する. 一方, JJA 季（6 月中旬～ 8 月中

1）干113 東京都文京区本郷7-3-1 東京大学理学部地理学教室

2) 干390 長野県松本市旭3-1-1 信州大学経済学部

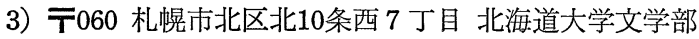

4） ₹112 東京都文京区大塚2-1-1 特茶の水女子大学文教育学部地理学教室

5） ₹113 東京都文京区弥生2-11-16 東京大学理学部物地球理学教室 
旬）には，それはアフリカ北部から西アジアにかけて分 布する. 南半球では, DJF 季には, 平均無降水域は各大 陸の西岸に限られて分布するが, JJA 季には各大陸に広 く分布し, また, 極小無降水域が南アメリカの北東部に 出現する. 無降水域の季節内での変動は, DJF 季の北 アメリカ北部とオーストラリアで特に大きい.

以上 2 季節の無降水域の分布の解析結果から， 4 つの 季節無降水域を設定した．それらは，冬と夏の極小無降 水域 (mNPA), 冬之夏の平均無降水域 (wsNPA), 冬の 又の平均無降水域 (wNPA) と夏の久の平均無降水 域
(sNPA) である. 大陸の西部では mNPA と wsNPA が広く分布し，かつすべての無降水域型が帯状に並列し ている. 各大陸の西部では, 各無降水域型がアリソフや ケッペンの気候型とよく対応している. しかし，大陸の 東部には， wNPA が現われるか，または無降水域は まったく出現せず，アリソフやケッペンの各気候型との 関連も良くない，無降水域の分布からみると，各大陸の 東部と西部との境は, 各大陸上でもっとも高い山脈の西 側に位置することが明らかになった。 